\title{
Regulatory Effects of Mesenchymal Stem Cells in Brain
}

\author{
Kulchitsky Vladimir*1, Zamaro Alexandra ${ }^{1}$, Navitskaya Valeria ${ }^{2}$, Koulchitsky Stanislav ${ }^{3}$ and Shanko Yuri ${ }^{2}$ \\ ${ }^{1}$ Institute of Physiology, National Academy of Sciences, Minsk, Belarus
}

${ }^{2}$ Republican Scientific and Practical Center of Neurology and Neurosurgery, Minsk, Belarus

${ }^{3}$ University of Liège, Liege, Belgium

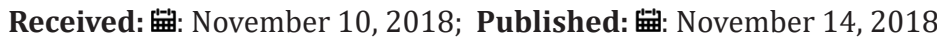

*Corresponding author: Kulchitsky Vladimir, Institute of Physiology, National Academy of Sciences, Minsk, Belarus

\begin{abstract}
The question on various functional effects of mesenchymal stem cells (MSCs) during different pathological processes development in brain was considered. Attention was paid to ability of MSCs to be involved in control of reparative processes in nerve tissue due to expression of many neurotrophic factors. Such feature of MSCs enhances their positive effects by realization of another potential - ability to progress in neuron-like direction. They also have an impressive ability to interact with immune competent cells in brain tissue to increase antitumor effect. It was shown that MSCs are able to synthesize and express lots of regulatory factors which inhibit growth of glioma cells. Therefore, vision of MSCs functional heterogeneity was expanded and their various regulatory effects were combined in realization of protective function both in health and disease.

Keywords: Antitumor Effects; Brain Plasticity; Defensive Reactions; Neurotrophic Factors; Reparative Processes; Stem Cells; Transcription Factors Abbreviations: Ad-HMSCs: Adipose Human Mesenchymal Stem Cells; BDNF: Brain Derived Neurotrophic Factor; GDNF: Glial Cell Derived Neurotrophic Factor; NGF: Nerve Growth factor; NGFR: Nerve Growth Factor Receptor; MSCs: Mesenchymal Stem Cells; SCs: Stem Cells; Sox: (Sryrelated HMG box) genes encode transcription factors
\end{abstract}

\section{Introduction}

Cellular technologies are being widely implemented into many spheres of practical medicine recently. The number of advanced technologies involving stem cells (SCs) progressively increases in treatment of brain diseases. Specialists think SCs are able to grow in neuron-like direction in damaged brain regions showing various regulatory effects in health and disease (Alzheimer's disease, stroke, brain trauma, glioma, glioblastoma) [1-6]. Mesenchymal stem cells (MSCs) seem the most promising besides residential brain cells. MSCs are administered mainly systemically for correction of impaired brain functions in the development of pathological processes. For example, MSCs have wide potential for the treatment of Alzheimer's disease [1,7]. It has been suggested that reparative processes in the brain are activated by secretion of nerve growth factor (NGF), brain-derived neurotrophic factor (BDNF), and vascular endothelial growth factor (VEGF) from neural SCs [8].The search for "Neurotrophic Effect Stem Cells Brain" and "Neurotrophic Effect Mesenchymal Stem Cells Brain" in PubMed on November 7"th 2018 showed 491 and 153 articles, respectively, and the interest started to grow only eight-nine years ago. Scientists and physicians are interested in two aspects of MSCs functional role in brain: reparative potential of MSCs, and antitumor potential of MSCs.

\section{Reparative Potential of MSCs}

First of all, enhancement of reparative potential of residential stem cells in patient's brain by autologous MSCs is a promising field. Only 27 articles have been found in PubMed while searching for "Neurotrophic Effect Mesenchymal Stem Cells Brain repair". Their authors stress that despite of low amount of publications cellular technologies of MSCs use are promising addition to current methods of neurodestructive processes treatment [3,4,6,9-11]. According to range of authors, intravenous injection of allogeneic MSCs from adipose tissue in patients with acute stroke can be safe therapy and increase recovery of nerve tissue and blood flow in cerebral vessels [8]. Brain-derived neurotrophic factor (BDNF) is mentioned as one of the key trophic factors which MSCs express in damaged brain area $[8,9]$. It was assumed, following experimental modeling of neonatal stroke in rats, that intranasal administration of MSCs could be useful in brain functions recovery after stroke $[3,4,6]$. The technique of intranasal administration of MSCs after modeling of neurodestructive processes in different parts of brain and spinal cord was thoroughly substantiated [2-4]. Somatotopic principle of MSCs migration to damaged brain region was established for the 
first time: MSCs move along chosen cranial nerve to anterior or posterior cranial fossae depending on damage localization [4].

\section{Antitumor Potential of MSCs}

Secondly, recent results showed that MSCs have potential for inhibition of glioma cells growth $[12,13]$. It was based on revealed MSCs taxis to tumor cells [6]. PubMed search for "Neurotrophic Effect Mesenchymal Stem Cells Brain glioma" and "Mesenchymal Stem Cells Brain glioma" on November 7th, 2018 revealed one and 386 articles, respectively. Articles demonstrate how MSCs actively interact with components of immune system and show both antiinflammatory and antitumor effects [13].

MSCs serve as attractive instrument for cellular therapy of cancer due to their ability to migrate to tumors and express bioactive molecules. However, influence of MSCs on tumor growth was not completely established. Authors [2,7,13] performed systemic injection of MSCs to femoral vein, or carotid artery. Same authors [14] showed that intracerebral injection of Ad-hMSC significantly improved survival rate of rats with heterotransplants U87MG. This effect was associated with decrease of tumor growth due to limitation of tumor cells proliferation and decrease of microvessel density. Fetal injection of Ad-hMSC lowered population of tumor cells and initiated migration of residential microglia cells in GSC1 heterotransplants. It is known that Sox21 inhibits glioma progression, because Sox 21 decrease the stem-like cell properties of the tumor cells [15]. Induction of Sox21 in the glioma resulted in a significant smaller tumor size [15]. But, still there is no clarity in the answer to the question of how the intercellular, perineural and perivascular spaces of the brain create conditions for the migration of stem cells [16].

Gathered data can say for broadening of MSCs antitumor potential use in combination with standard surgical, radio- and chemotherapeutical, and especially with such methods which are aimed at activation of immune system [17,18], delivery of metabolizing genes and/or oncolytic viruses [19].

\section{Conclusion}

Functional heterogeneity of MSCs which is demonstrated in various regulatory effects is the basis for extension of stem cells use in guidelines dedicated to treatment of socially important diseases. It should be mentioned that lots of MSCs effects are still underexplored. For example, we don't know all of side effects, including possibility of MSCs to transform to cancerogenic cells. Deepening of knowledge on fundamental and applied aspects of MSCs use in experiments and practice will allow reasonable use of protective function of MSCs in health and disease.

\section{Acknowledgement}

Our research project was partially sponsored by SSTP "New methods of medical care", section "Transplantation of cells, tissues and organs" (2016-2020), and by grant 000 "Synergy".

\section{References}

1. Kulchitsky V, Zamaro A, Navitskaya V, Yuri Shanko Y, Svetlana Pashkevich S, et al. (2018) Perspectives of stem cells use in alzheimer's disease treatment. J Neurol Stroke 8(3): 190-191.
2. Kulchitsky V, Zamaro A, Shanko Y, Koulchitsky S (2018) Positive and negative aspects of cell technologies in cerebral diseases. J Neurol Stroke 8(2): 87-88.

3. Shanko Y, Navitskaya V, Zamaro A, Krivenko S, Zafranskaya M, et al. (2018) Prospects of Perineural Administration of Autologous Mesenchymal Stem Cells of Adipose Tissue in Patients with Cerebral Infarction. Biomed J Sci \& Tech Res 10(1): 1-3.

4. Shanko Y, Navitskaya V, Zamaro A, Zafranskaya M, Krivenko S, et al. (2018) Somatotopic principle of perineural implantation of stem cells in patients with brain injuries. J Neurol Stroke 8(5): 259-261.

5. Kulchitsky V, Koulchitsky S (2018) Biomedical Prospects for The Use of Stem Cells for The Treatment of Gliomas. Biomed J Sci \&Tech Res 4(5): $1-3$.

6. Shanko Y, Zamaro A, Takalchik-Stukach Y, Koulchitsky S, Pashkevich S, et al. (2018) Mechanisms of Neural Network Structures Recovery in Brain Trauma. Biomed J Sci \& Techn Res 7(5): 1-2.

7. Huang C, Gan D, Fan C, Wen C, Li A, et al. (2018) The Secretion from Neural Stem Cells Pretreated with Lycopene Protects against tert-Butyl Hydroperoxide-Induced Neuron Oxidative Damage. Oxid Med Cell Longev 2018: 5490218.

8. Martins LF, Costa RO, Pedro JR, Aguiar P, Serra SC, et al. (2017) Mesenchymal stem cells secretome-induced axonal outgrowth is mediated by BDNF. Sci Rep 7(1): 4153.

9. Díez-Tejedor E, Gutiérrez-Fernández M, Martínez-Sánchez P, Rodríguez-Frutos B, Ruiz-Ares G, et al. (2014) Reparative therapy for acute ischemic stroke with allogeneic mesenchymal stem cells from adipose tissue: A safety assessment: A phase II randomized, double-blind, placebo-controlled, single-center, pilot clinical trial. J Stroke Cerebrovasc Dis 23(10): 2694-2700.

10. Song Q, Xu R, Zhang Q, Ma M, Zhao X (2014) Therapeutic effect of transplanting bone mesenchymal stem cells on the hind limbs' motor function of rats with acute spinal cord injury. Int J Clin Exp Med 7(1): 262-267.

11. Van Velthoven CT, Sheldon RA, Kavelaars A, Derugin N, Vexler ZS, et al. (2013) Mesenchymal stem cell transplantation attenuates brain injury after neonatal stroke. Stroke 44(5): 1426-1432.

12. Jiao H, Yang B, Guan F, Li J, Shan H et al. (2011) The mixed human umbilical cord blood-derived mesenchymal stem cells show higher antitumor effect against C6 cells than the single in vitro. Neurol Res 33(4): 405-414.

13. Aboody KS, Brown A, Rainov NG, Bower KA, Liu S, et al. (2000) Neural stem cells display extensive tropism for pathology in adult brain: Evidence from intracranial gliomas. Proc Natl Acad Sci USA 97: 1284612851.

14. Pacioni S, D’Alessandris QG, Giannetti S, Morgante L, Coccè V, et al. (2017) Human mesenchymal stromal cells inhibit tumor growth in orthotopic glioblastoma xenografts. Stem Cell Res Ther 8(1): 53.

15. Caglayan D, Lundin E, Kastemar M, Westermark B, Ferletta M (2013) Sox21 inhibits glioma progression in vivo by forming complexes with Sox2 and stimulating aberrant differentiation. Int J Cancer 133(6): 13451356.

16. Segarra M, Kirchmaier BC, Acker-Palmer A (2015) A vascular perspective on neuronal migration. Mech Dev 138(1): 17-25.

17. Jia XH, Feng GW, Wang ZL, Du Y, Shen C, et al. (2016) Activation of mesenchymal stem cells by macrophages promotes tumor progression through immune suppressive effects. Oncotarget 7(15): 20934-20944.

18. Kraśko JA, Žilionytė K, Darinskas A, Strioga M, Rjabceva S, et al. (2017) Bacterial ghosts as adjuvants in syngeneic tumour cell lysate-based anticancer vaccination in a murine lung carcinoma model. Oncol Reports 37(1): 171-178.

19. Namba H, Kawaji H, Yamasaki T (2016) Use of genetically engineered stem cells for glioma therapy. Oncol Lett 11(1): 9-15. 


\section{ISSN: 2574-1241}

DOI: $10.26717 / B J S T R .2018 .11 .002039$

Kulchitsky Vladimir. Biomed J Sci \& Tech Res

(C) (i) This work is licensed under Creative

Commons Attribution 4.0 License

Submission Link: https://biomedres.us/submit-manuscript.php

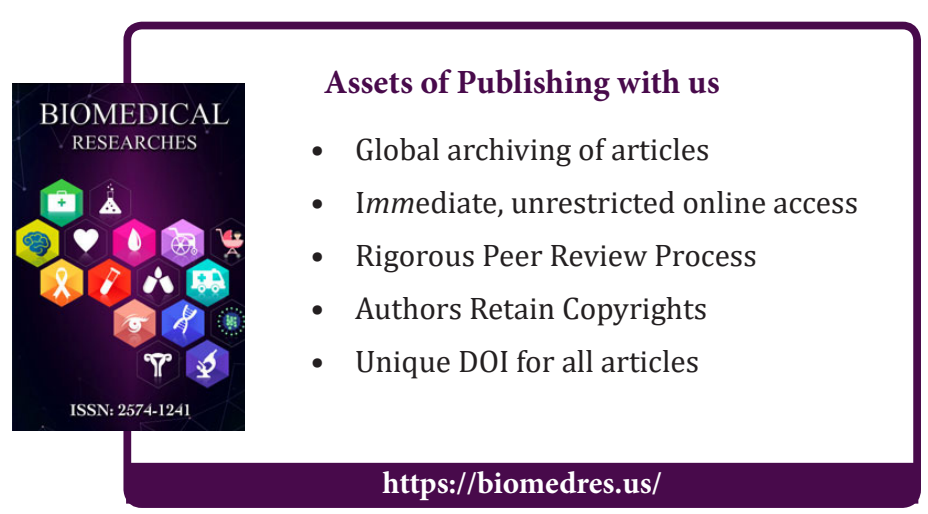

